\title{
Article
}

\section{Study on Land Use/Cover Change and Ecosystem Services in Harbin, China}

\author{
Dao Riao ${ }^{1,2,3}$, Xiaomeng Zhu ${ }^{1,4}$, Zhijun Tong ${ }^{1,2,3, *}$, Jiquan Zhang $1,2,3, * \mathbb{C}$ and Aoyang Wang ${ }^{1,2,3}$ \\ 1 School of Environment, Northeast Normal University, Changchun 130024, China; \\ daora388@nenu.edu.cn (D.R.); zhuxm712@nenu.edu.cn (X.Z.); wangay950@nenu.edu.cn (A.W.) \\ 2 State Environmental Protection Key Laboratory of Wetland Ecology and Vegetation Restoration, \\ Northeast Normal University, Changchun 130024, China \\ 3 Laboratory for Vegetation Ecology, Ministry of Education, Changchun 130024, China \\ 4 Shanghai an Shan Experimental Junior High School, Shanghai 200433, China \\ * Correspondence: gis@nenu.edu.cn (Z.T.); zhangjq022@nenu.edu.cn (J.Z.); \\ Tel.: +86-1350-470-6797 (Z.T.); +86-135-9608-6467 (J.Z.)
}

Received: 18 June 2020; Accepted: 25 July 2020; Published: 28 July 2020

check for updates

\begin{abstract}
Land use/cover change (LUCC) and ecosystem service functions are current hot topics in global research on environmental change. A comprehensive analysis and understanding of the land use changes and ecosystem services, and the equilibrium state of the interaction between the natural environment and the social economy is crucial for the sustainable utilization of land resources. We used remote sensing image to research the LUCC, ecosystem service value (ESV), and ecological economic harmony (EEH) in eight main urban areas of Harbin in China from 1990 to 2015. The results show that, in the past 25 years, arable land-which is a part of ecological land-is the main source of construction land for urbanization, whereas the other ecological land is the main source of conversion to arable land. There is no significant change in the value ratio of ESV, however, it is also inclined to the southeast of the study area in spaces like the barycenter of LUCC. The EEH degree has risen from the potential crisis area to the medium coordination degree, and then dropped to the low coordination degree. This shows that although there has been limited change of LUCC, ESV, and EEH in eight main urban areas of Harbin in 25 years, there is a contradiction between the allocation of ecological land and non-ecological land.
\end{abstract}

Keywords: land use/cover change; ecosystem service value; ecological economic harmony; Harbin

\section{Introduction}

The definition of the use of environmental resources changes with the advancement of society and human needs. Urbanization is the inevitable outcome and spatial manifestation of social and economic development. However, the earth's resource carrying capacity is limited. Blind and unrestricted use of resources and the environment will eventually result in resource depletion. Resource depletion will lead to the degradation of the environment and various ecological service functions, thus inhibiting the advancement of society and human needs [1-6].

In the 1990s, the International Geosphere-Biosphere Program (IGBP) and the International Human Dimensions Program on Global Environmental Change (IHDP) jointly developed and published the Scientific Research Plan of land use/cover change (LUCC) [7-9], which focuses on the mechanisms of land use and land cover change, and integrated models at regional and global scales. Since then, many international organizations and countries working on global environmental change have undertaken research and initiated their own LUCC research projects. The goal of these policies and efforts is to protect and restore the ecological environment in parallel with economic development, to promote 
synergistic development of the economy and the ecological environment, and to emphasize the "value" of ecological land.

Change of land use, a process referred to as land urbanization, is the most direct path in accelerating urbanization. In this process, various issues have been highlighted that need to be recognized, evaluated, and solved in a coordinated way. These issues include low land utilization rate, damage to the quality of arable land, threat to the red line of arable land and food security, uncoordinated development of land urbanization and population urbanization, massive encroachment of urban construction land on ecological land, and degradation of the quality of ecological land $[10,11]$. These issues have been recognized and human beings have begun to implement a series of policies and practices for change. The results of China's second national land survey show that the data of ecological land use have changed significantly, and the issue of ecological carrying capacity is becoming increasingly pronounced in China.

Although some developed countries and China have different resource conditions and land ownership systems, China has much to learn in terms of management and policy. For example: (1) Although the United States does not have a separate land use planning system, the land use planning system is part of general planning at all levels. It is viewed as an aspect of public planning and social control and is the most important plan in social and economic planning. It is characterized by macro-control and flexible policy changes, with the goal of promoting the sustainable use and development of land resources; (2) Japan combines macro-management and micro-management of land use through legal and administrative means. It is characterized by an emphasis on integrated macro management and indirect micro regulation.

Presently, China has policies such as the Sustainable Development Strategy, Community of Shared Life, Grain for Green, the Increase Link the Decrease, Increasing Deposit Linkage, Space Control, Ecological City, and Three Lines and One List [12-17]. All these policies and works focus on LUCC research. LUCC is one of the important responses of global environmental change, terrestrial ecosystems, global climate change, and human activities. The objectives of these policies and practices are to protect and repair the ecological environment while developing the economy, to promote the coordinated development of the economy and the ecological environment, and to attach importance to the "value" of the ecological environment. We must step up efforts to promote the construction of ecological civilization, continue implementing the strictest land conservation system without swerving, control the delivery of incremental land, increase the activation of stock land, optimize the spatial layout and structure of land use, and improve the efficiency of land use [7-9,18].

The terrestrial ecosystem is the foundation for human survival and sustainable development, and is also one of the core elements of global change research. As the leading driving factor of ecosystem services, land use plays the role of a "bridge" in linking human activities with ecosystem services. Improvement of human ability and consciousness to make structural changes to layout of land use/cover will have a strong impact on the composition, structure, and function of the ecosystem [19-21]. With the implementation of the sustainable development strategy and the spread of the idea of the construction of ecological civilization, Ministry of Environmental Protection of the People's Republic of China has approved a total of seven pilot ecological provinces and vigorously promoted the work of ecological provinces, cities, and counties. In 2018, China carried out institutional reforms and established the Ministry of Natural Resources and the Ministry of Ecological Environment, taking natural resources as a whole. As part of institutional reforms, the "Third National Land Survey" was renamed the "Third National Land and Resource Survey."

Heilongjiang Province is one of the seven pilot ecological provinces in China. Harbin, the capital city of Heilongjiang Province, is an important central and representative city in northeast China. A comprehensive analysis and understanding of the changing and evolving characteristics of the spatial pattern of land use change and ecosystem services, exploring the relationship between them, and the state of interaction between the natural environment and socio-economics will help to capture the ecological and environmental effects of LUCC. It can provide a scientific basis for the optimal 
allocation of land use in the three northeastern provinces of China (Heilongiiang, Jilin, Liaoning), China as a whole, and other developing countries, and play a representative role in ensuring ecological security and sustainable development [22].

\section{Materials and Methods}

\subsection{Study Area}

According to the "Harbin City Master Plan (2011-2020)" [23], the research area is defined as the main urban area in Harbin, which includes eight districts: Daoli district, Daowai district, Nangang district, Xiangfang district, Pingfang district, Songbei district, Hulan district, and Acheng district.

Harbin, also known as ice city, is located in the northeastern plain of the People's Republic of China and the south of Heilongjiang Province, E $125^{\circ} 42^{\prime}-130^{\circ} 10^{\prime}$ and $N 44^{\circ} 04^{\prime}-46^{\circ} 40^{\prime}$ (Figure 1). It has a continental monsoon climate in the middle temperate zone, with long winters and short summers. All the rivers in Harbin belong to the Songhua River system and Mudanjiang River system. The annual average precipitation is $569.1 \mathrm{~mm}$, most of which falls from June to September. Harbin is the capital city of Heilongjiang Province, a deputy provincial city and an important central city approved by the State Council of the people's Republic of China in northeast China. Moreover, it is an important manufacturing base in China, an internationally famous city for the ice and snow culture, and one of the seven pilot ecological provinces in China.

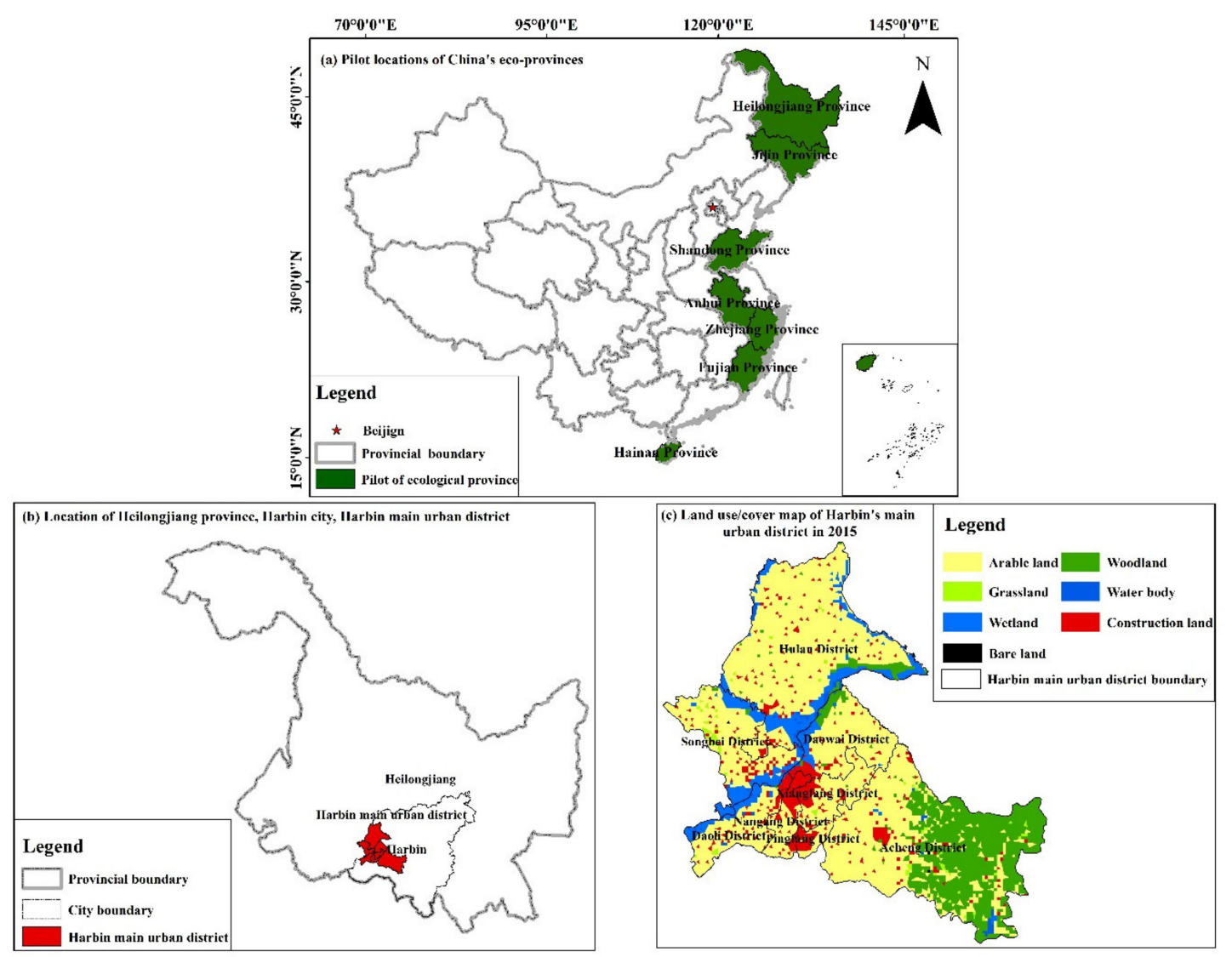

Figure 1. The location and land use/cover map of Harbin's main urban district in 2015.

\subsection{Data Source}

The dataset (from 1990-2015) is provided by Data Center for Resources and Environmental Sciences, Chinese Academy of Sciences (RESDC) (http://www.resdc.cn), and includes six phases of $1 \mathrm{~km}$ land use grid data from 1990, 1995, 2000, 2005, 2010, and 2015. On the website, China's multi-period land use/cover remote sensing monitoring data set (CNLUCC) mainly uses Landsat TM/ETM remote 
sensing images of US land satellites as the information source. The dataset is one of the most accurate land use remote sensing monitoring data products in China. The application field has been involved in all aspects of the national economy, and has become a convenient and effective data support, which initially formed a stable group of data users.

The process of dataset is completed in four steps-image preprocessing, artificial visual interpretation, dynamic information acquisition, and field verification. Field verification shows that the accuracy rate of land use classification in the three seasons is higher than $90 \%$.

According to the actual context of Harbin and the requirements of this study, the type of land use/cover are divided into two primary-classification and seven secondary-classification types of land use/cover types, as shown in Table 1 [22].

Table 1. Land use/cover classification system of Harbin main urban district.

\begin{tabular}{ccc}
\hline Primary Classification & Secondary Classification & Include \\
\hline Ecological land & Arable land & Woodland \\
& Grassland & $\begin{array}{c}\text { Paddy field, Dry farmland } \\
\text { Forest land, Shrub land, Sparse woodland, Other woodland } \\
\text { High-coverage grassland, Medium-coverage grassland, } \\
\text { Low-coverage grassland }\end{array}$ \\
& Wetland & $\begin{array}{c}\text { Ditch, Lake, Reservoir pit, Permanent Glacial Snow fields } \\
\text { Intertidal zone, Shoal, Marshland }\end{array}$ \\
Non-ecological land & Construction land & Urban land, Rural settlements, Other construction land \\
& Bare land & $\begin{array}{c}\text { Oand land, Gobi, Saline-alkali land, Bare land, Bare rock land, } \\
\text { Other land }\end{array}$ \\
\hline
\end{tabular}

\subsection{Methods}

\subsubsection{Land Use/Cover Change}

(1) Quantify structure

The dynamic degree of LUCC quantitatively describes the speed of change and the intensity of change of a specific type of land use/cover within the study area. It is based on the area of its land use type and is concerned with the average annual change over a period of time. It has been used by many scholars to compare and predict differences and trends in land use/cover change [24-27].

$$
K_{i}=\left[\left(u_{i b}-u_{i a}\right) / u_{i a}\right] \times T^{-1} \times 100 \%
$$

In the formula, $K_{i}$ represents the dynamic degree of change of the $i$ land use/cover type, $u_{i a}$ and $\mathrm{u}_{i b}$ represent the initial and final total areas of the $i$ land use/cover type in the study period $\left(\mathrm{km}^{2}\right)$, respectively. $T$ is the duration of the study, and the unit in this study is year.

\section{(2) Spatial pattern}

The shift of land use barycenter represents the situation in which a land pattern is used in the study area. The United States made calculations in the 1970s about the shift of barycenter of the U.S. population from the mid-19th century to the 1970s. The barycenter of land use/cover is proposed based on the barycenter theory of population distribution, which is used to characterize the spatial position and change of the barycenter in the process of land development and utilization. The position of the barycenter is generally expressed by the latitude and longitude of the map [28,29]. In this study, we used ArcGIS software to calculate and produce the figure.

$$
\begin{aligned}
& X_{t}=\sum_{i=1}^{n}\left(s_{t i} \times X_{i}\right) / \sum_{i=1}^{n} s_{t i} \\
& Y_{t}=\sum_{i=1}^{n}\left(s_{t i} \times Y_{i}\right) / \sum_{i=1}^{n} s_{t i}
\end{aligned}
$$


In the formula, $X_{t}$ and $Y_{\mathrm{t}}$ represent the coordinates of the longitude and latitude of the $i$ land use/cover type barycenter in year $T$, respectively. $S_{t i}$ represents the total area of the $i$ land use/cover type in year $T\left(\mathrm{~km}^{2}\right), X_{t}$ and $Y_{\mathrm{t}}$ represent the coordinates of the longitude and latitude of the geometric center of area under the $i$ land use/cover type, respectively.

Spatial adjacency probability of land use/cover types can represent the degree of adjacency of a certain land use/cover type to that of other land use/cover types [30-32].

$$
A M_{i j}=T_{i j} / T_{i i}
$$

In the formula, $A M_{i j}$ represents the degrees of adjacency between the $i$ land use/cover type and the $j$ land use/cover type, $0<A M_{i j}>100 \%$. $T_{i j}$ represents the grid number of the $j$ land use/cover type patches adjacent to the $i$ land use/cover type, and $T_{i i}$ represents the grid number of the $i$ land use/cover type patches adjacent to themselves.

The spatial conversion trend index of land use/cover type is used to express the trend index of transformation from the $i$ land use/cover type to the $j$ land use/cover type, when the $i$ type land use/cover patches is adjacent to the $j$ land use/cover type patches [30-32].

$$
\begin{gathered}
f_{i j}=Y_{i j} / Y_{j i} \\
Y_{i j}=P_{i j} / A M_{i j}
\end{gathered}
$$

In the formula, $f_{i j}$ represents the trend index from the $i$ land use/cover type to the $j$ land use/cover type, when the $i$ land use/cover type patches are adjacent to the $j$ land use/cover type patches. $P_{i j}$ represents the rate of change of the land use/cover type from $i$ to $j$ in the study period, and $A M_{i j}$ represents the degree of adjacency between the $i$ land use/cover type to the $j$ land use/cover type.

\subsubsection{Ecosystem Service Value}

Ecosystem service refers to the environmental conditions and natural utility that are formed and maintained by ecosystems and ecological processes on which human beings depend for their survival [33-37].

The ecosystem services function is divided into four first-class and nine second-class orders [33-37]. According to historical literature and the appropriate adjustment of the ecosystem service equivalent value developed by Xie Gaodi scholars, the ecosystem service value equivalent of Harbin will be obtained, as shown in Table 2. Although construction land has a negative impact on the ecological environment, the ecosystem service value does not depict negative values. Therefore, in the study, the ecosystem service value equivalent of the construction land only includes positive indexes such as

\begin{tabular}{|c|c|c|c|c|c|c|c|c|}
\hline $\begin{array}{l}\text { Primary } \\
\text { Type }\end{array}$ & Secondary Type & $\begin{array}{c}\text { Arable } \\
\text { Land }\end{array}$ & $\begin{array}{l}\text { Wood- } \\
\text { Land }\end{array}$ & $\begin{array}{l}\text { Grass- } \\
\text { Land }\end{array}$ & $\begin{array}{l}\text { Water } \\
\text { Body }\end{array}$ & Wet-Land & $\begin{array}{c}\text { Construction } \\
\text { Land }\end{array}$ & $\begin{array}{l}\text { Bare } \\
\text { Land }\end{array}$ \\
\hline \multirow{2}{*}{$\begin{array}{l}\text { Supply } \\
\text { service }\end{array}$} & Food production & 1 & 0.33 & 0.43 & 0.53 & 0.36 & 0 & 0.02 \\
\hline & Raw material production & 0.39 & 2.98 & 0.36 & 0.35 & 0.24 & 0 & 0.04 \\
\hline \multirow{4}{*}{$\begin{array}{l}\text { Mediation } \\
\text { service }\end{array}$} & Gas regulation & 0.72 & 4.32 & 1.5 & 0.51 & 2.41 & 0 & 0.06 \\
\hline & Climate regulation & 0.97 & 4.07 & 1.56 & 2.06 & 13.55 & 0 & 0.12 \\
\hline & Hydrological regulation & 0.77 & 4.09 & 1.52 & 18.77 & 13.44 & 0 & 0.07 \\
\hline & Waste disposal & 1.39 & 1.72 & 1.32 & 14.85 & 14.4 & 0.25 & 0.26 \\
\hline \multirow{2}{*}{$\begin{array}{l}\text { Support } \\
\text { services }\end{array}$} & Maintain soil & 1.47 & 4.02 & 2.24 & 0.41 & 1.99 & 0 & 0.17 \\
\hline & Maintain biodiversity & 1.02 & 4.51 & 1.87 & 3.43 & 3.69 & 0.4 & 0.4 \\
\hline \multirow[t]{2}{*}{$\begin{array}{l}\text { Cultural } \\
\text { services }\end{array}$} & Provide aesthetic landscape & 0.17 & 2.08 & 0.87 & 4.44 & 4.69 & 0.24 & 0.24 \\
\hline & Total & 7.9 & 28.12 & 11.67 & 45.35 & 54.77 & 0.89 & 1.38 \\
\hline
\end{tabular}
waste treatment, biodiversity maintenance, and aesthetic landscape provision.

Table 2. Equivalent coefficient of ecosystem service value in Harbin main urban district. 
Based on the data of Harbin Statistical Yearbook and ecosystem service value equivalent, we can analyze the characteristics of change of the Harbin ecosystem service value over the years.

\subsubsection{Ecological Economic Harmony}

Ecological economic harmony $(\mathrm{EEH})$ represents the state of the interaction between the natural environment and the social economy [38-42]. The degree of ecological economic harmony is an important index for determining the existence of coordination between the ecological environment and the economy in the research area during the research period. Chinese scholars such as Wang Zhenbo and Su Fei have used the ratio of ecosystem service value to GDP to construct the EEH index, which has since been widely used. Presently, the degree of coordination of the ecological economy has become a hot topic in academic circles; however, the calculation results have not been standardized for classification and grading. Therefore, the calculation results in this study are based on previous researches conducted by various scholars to assess the degree of eco-economic coordination in the study area [38-42].

$$
\begin{gathered}
E E H=E S V_{T} / G D P_{T} \\
E S V_{T}=\left(E S V_{b}-E S V_{a}\right) / E S V_{a} \\
G D P_{T}=\left(G D P_{b}-G D P_{a}\right) / G D P_{a}
\end{gathered}
$$

In the formula, $E E H$ represents the degree of coordination of the eco-economic system in the study area during the study period. $E S V_{a}$ and $E S V_{b}$ represent the value of the ecosystem service per unit area in the initial and final sections of the study area, respectively (ten thousand Yuan/ $/ \mathrm{km}^{2}$ ). GDP and $G D P_{b}$ represent the GDP per unit area in the initial and final sections of the study area, respectively (ten thousand Yuan $/ \mathrm{km}^{2}$ ).

\section{Results}

\subsection{Evolution Characteristics of Land Use/Cover Change}

\subsubsection{Change Characteristics of Quantitative Structure}

As shown in Table 3, the dynamic number of LUCCs in Harbin over the years have both positive and negative values; the decrease (negative values) are mostly in ecological land use whereas the increase (positive values) are in the non-ecological land-construction land part. This shows that, although the dynamic degree of LUCCs in the study area is not more than $6 \%$, the range of change is narrow; however, there are obvious differences between the ecological and non-ecological LUCCs. Besides the water body area, the remaining ecological land is decreasing by an overall proportion of $0.07 \%$. The proportion of construction land area in non-ecological land has increased over 25 years by $1.10 \%$ overall, without any change in bare land. In the past 25 years, the highest value was in the

\begin{tabular}{|c|c|c|c|c|c|c|c|}
\hline Type of LUCC & 1990-1995 & 1995-2000 & 2000-2005 & 2005-2010 & 2010-2015 & \multicolumn{2}{|c|}{ 1990-2015 } \\
\hline Arable land & $0.21 \%$ & $-0.006 \%$ & $-0.14 \%$ & $-0.05 \%$ & $-0.24 \%$ & $-0.04 \%$ & \multirow{5}{*}{$-0.07 \%$} \\
\hline Wood-land & $-0.29 \%$ & $-0.002 \%$ & $0.02 \%$ & $-0.01 \%$ & $-0.01 \%$ & $-0.06 \%$ & \\
\hline Grass-land & $-5.44 \%$ & $0.01 \%$ & $1.07 \%$ & $-0.93 \%$ & 0 & $-1.07 \%$ & \\
\hline Water body & $2.14 \%$ & 0 & $-0.08 \%$ & $-0.08 \%$ & $0.54 \%$ & $0.51 \%$ & \\
\hline Wet-land & $-0.89 \%$ & $0.05 \%$ & $0.06 \%$ & $-0.27 \%$ & $-0.16 \%$ & $-0.24 \%$ & \\
\hline Construction land & $0.59 \%$ & $0.01 \%$ & $1.19 \%$ & $0.97 \%$ & $2.31 \%$ & $1.11 \%$ & \multirow{2}{*}{$1.10 \%$} \\
\hline Bare land & 0 & 0 & 0 & 0 & 0 & 0 & \\
\hline Total change & $0.40 \%$ & $0.01 \%$ & $0.19 \%$ & $0.13 \%$ & $0.34 \%$ & \multicolumn{2}{|c|}{$0.73 \%$} \\
\hline
\end{tabular}
construction land, whereas the lowest value was in the arable land.

Table 3. Dynamic degree of land use/cover change (LUCC) in Harbin main urban district. 
The dynamic degree of arable land change from 1990 to 1995 was positive, while the changes over the other years were negative. Among them, there was a pick-up from 2005 to 2010; however, from 2010 to 2015 the arable land change reached its lowest level in 25 years and showed a downward trend holistically. Although the dynamic degree of woodland change is negative except for the positive value from 2000 to 2005, the overall trend is on the rise, and after 1995 it approached zero. The dynamic degree of grassland change has fluctuated greatly in the past 25 years, with the largest dynamic change being experienced from 1990 to 1995, positive from 1995 to 2005, negative from 2005 to 2010, and zero from 2010 to 2015, showing an overall upward trend. The dynamic degree of change in water body cover was negative in two periods from 2000 to 2010, while the changes in the other years were positive, but the overall trend declined. The dynamic degree of wetland was positive in the two periods from 1995 to 2005, while the others were negative, but an overall increasing trend was observed. The dynamic degree of construction land change has been positive since 1990. Although it fluctuates up and down, it shows an obvious growth trend.

The dynamic degree of LUCC in the study area from 1990 to 2015 was $0.73 \%$, indicating that the change range in the study area was relatively small over the past 25 years. Among them, the dynamic degree of change was close to zero from 1995 to 2000, which indicates that the dynamic degree of LUCC in the study area from 1995 to 2000 is the lowest and is in a relatively stable state.

\subsubsection{Change Characteristics of Spatial Pattern}

As shown in Figure 1, the LUCC in the study area were mainly arable land, mostly occurring in the vast plain area in the middle, which is currently the main development and planned development area in the urban center of Harbin and is located at the terrace on both sides of Songhua River.

In the change of arable land, as shown in Figure 2, 73.5\% of the areas converted to construction land are mostly located in Nangang district, Xiangfang district, and Pingfang district, which is due to Harbin's "South Extension" policy. The other parts of the conversion to ecological land were due to "Grain for Green" and other policy actions such as ecological protection and land consolidation.
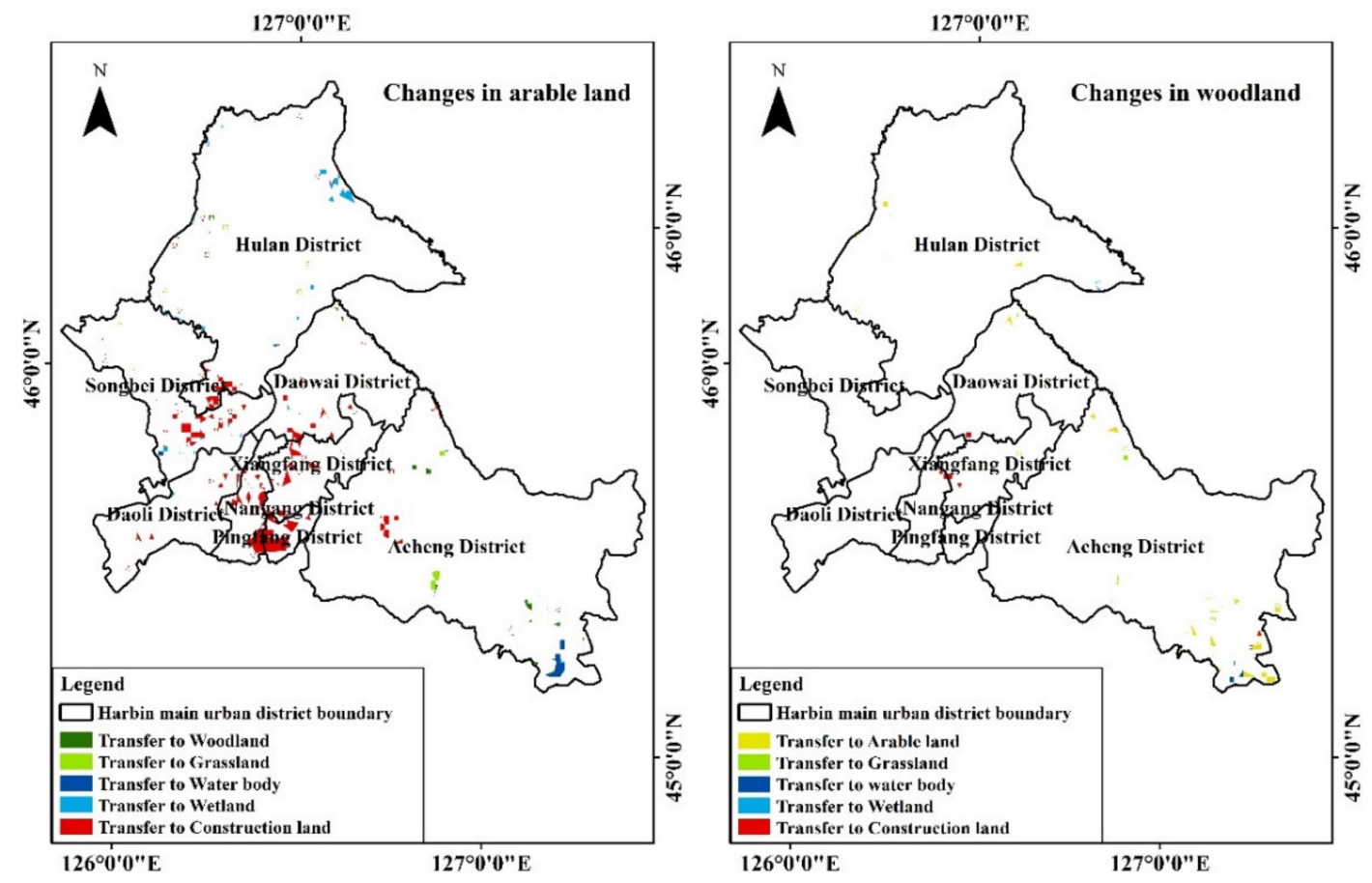

Figure 2. Cont. 

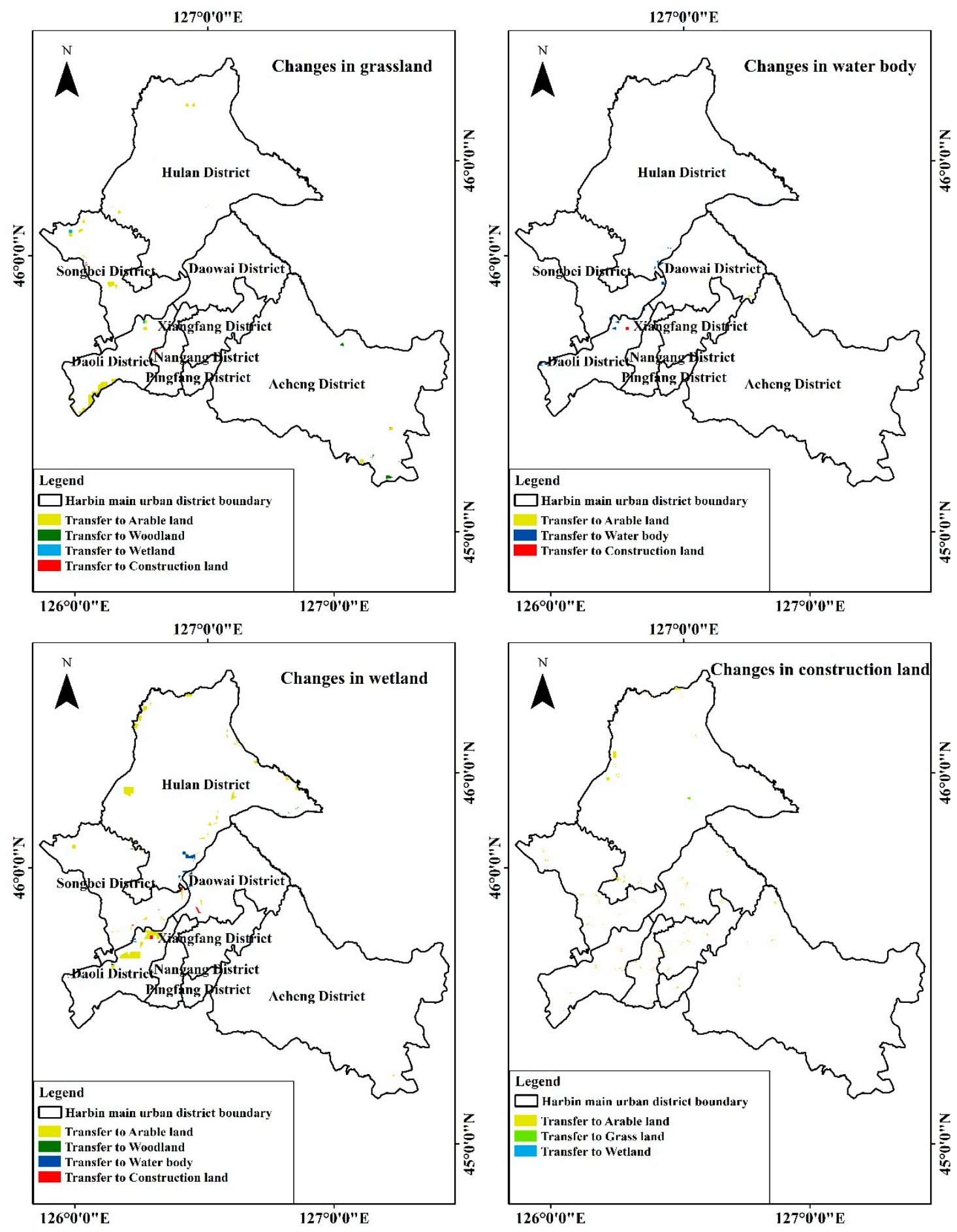

Figure 2. Cont. 


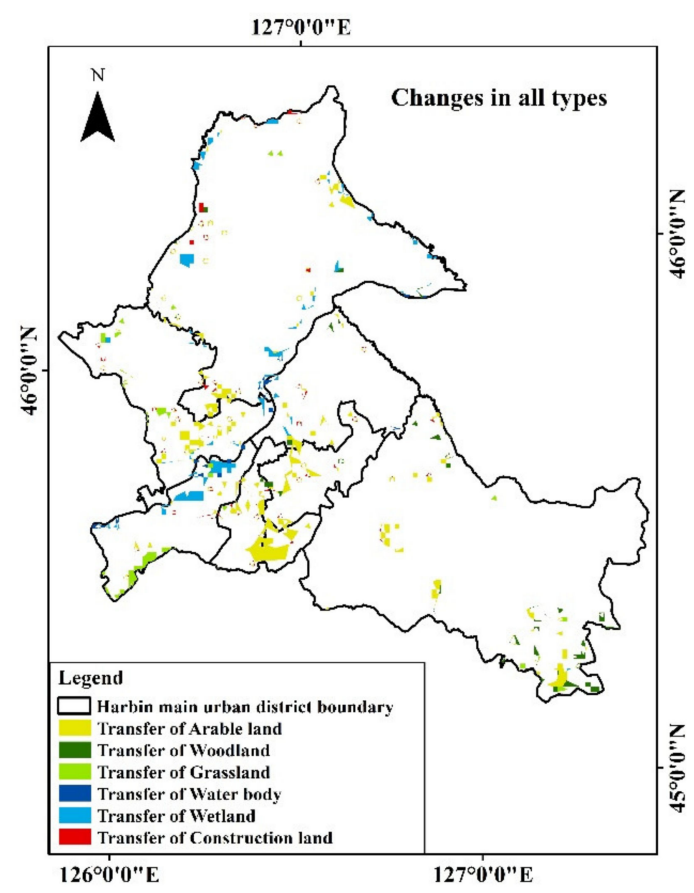

Figure 2. Regional distribution map of land use/cover change in Harbin main urban district

The woodland in the study area is concentrated in the southeast of the study area, which is located in the hilly area adjacent to the residual vein of Zhang Guangcai Ridge. The total change is small and scattered. Most of its changes have been through conversion to arable land, which is located in Acheng district. The proportion of grassland area in the study area is not large, and about one-third of the area has been converted to arable land, while the others were not more than $3 \mathrm{~km}^{2}$. Most of the changed areas are located in the south of Daoli district, and in the middle and north of Songbei district. Songhua River passes through the central part of Harbin City, most of the water body and wetland are transformed into each other, the part converted into other categories of land use/cover. Among them, the area of water body converted into wetland was the highest in the water body conversion area, while the area of the wetland that was converted into arable land was the highest of converted into arable land area. There are parts of construction land that were converted into arable land, grassland, and wetland, mostly located in the central and eastern parts of Hulan district [39-41], but the total area was small, and the biggest part was converted into arable land.

All seven types of land use/cover in Harbin, except bare land, have transfer-in and transfer-out areas. Four of the six types showed a reduced LUCC while only the area of water cover and construction land showed an increase, which is consistent with the above-mentioned in the previous section. The area of ecological land transferred to non-ecological land was the largest and is mostly located in the urban development center. The areas where ecological land was converted into ecological land are scattered and mostly located at the boundary of the study area. Limited parts of non-ecological land were transferred to ecological land and are located in the central and eastern parts of Hulan district.

As shown in Figure 3, the barycenter of the arable land in Harbin research area is located in the Daowai district and at the first terrace formed by Songhua River. Harbin is an important commodity grain production base in China due to its deep soil layer and fertile soil. However, Daowai district is also an area in the central part of Harbin City. With the acceleration of urbanization, the land in the original suburbs of the city has begun to urbanize, and various changes in land use/cover have taken place, shifting the barycenter of arable land use in Daowai district generally in the northwest direction, toward the north of the Songhua River bank at a distance of about $519 \mathrm{~m}$. Similar to the above contents, the longest distance over which the barycenter of arable land is shifted, was reported 
from 2010 to 2015, and was about 322 m, while the shortest distance was reported from 1995 to 2000, and was only about $5 \mathrm{~m}$.

Harbin woodland is seen to be concentrated in the entire southeast area of Acheng district. Based on the above-mentioned, it can be seen that the woodland area was reduced, and the southernmost part of Acheng district is one of the regions where LUCC is concentrated. From 1990 to 2015, the barycenter of the woodland moved to the east of the eastern boundary line of Acheng district in a general northeast direction and over a distance of $135 \mathrm{~m}$. Similar to the above contents, the longest shift distance of the woodland barycenter was about $205 \mathrm{~m}$ and had occurred between 1990 and 1995, while the shortest was about $22 \mathrm{~m}$ from 2005 to 2010.

The distribution of the grassland is located in Songbei district, Daoli district, and Acheng district. Due to the accelerated urbanization process, the urban area has increased, whereas the grassland area in Songbei district and Daoli district has begun to decrease. The barycenter of the grassland has shifted to the east of the study area, with a distance of approximately $9983 \mathrm{~m}$ in the northeast. Similar to the above contents, the longest shift distance of the grassland barycenter was from 1990 to 1995 and was about $4190 \mathrm{~m}$, and the shortest distance was reported from 2010 to 2015 with no shift of barycenter.

Songhua River runs from the central part of Harbin City. The city's water and wetland centers are located in Daowai and Hulan districts. According to the dynamic degree of LUCC, the water area increased from 1990 to 2015 . Therefore, the barycenter of the water body moved from the position near the shore of the off-road area to the south of the off-road area in a general southeast direction and for a distance of about $11,060 \mathrm{~m}$. Similar to the above contents, the longest distance over which the water body shifted its barycenter was reported from 1990 to 1995 and was about 11,150 m, while the shortest distance was reported from 1995 to 2000 with no shift in the barycenter. The barycenter of the wetland is located in Hulan district. From 1990 to 2015, it moved in the eastern direction of Hulan district in a general northeast direction and over a distance of $581 \mathrm{~m}$. Similar to the above contents, the longest shift distance of wetland barycenter was about $1134 \mathrm{~m}$ from 1990 to 1995, and the shortest was about $42 \mathrm{~m}$ from 1995 to 2000.
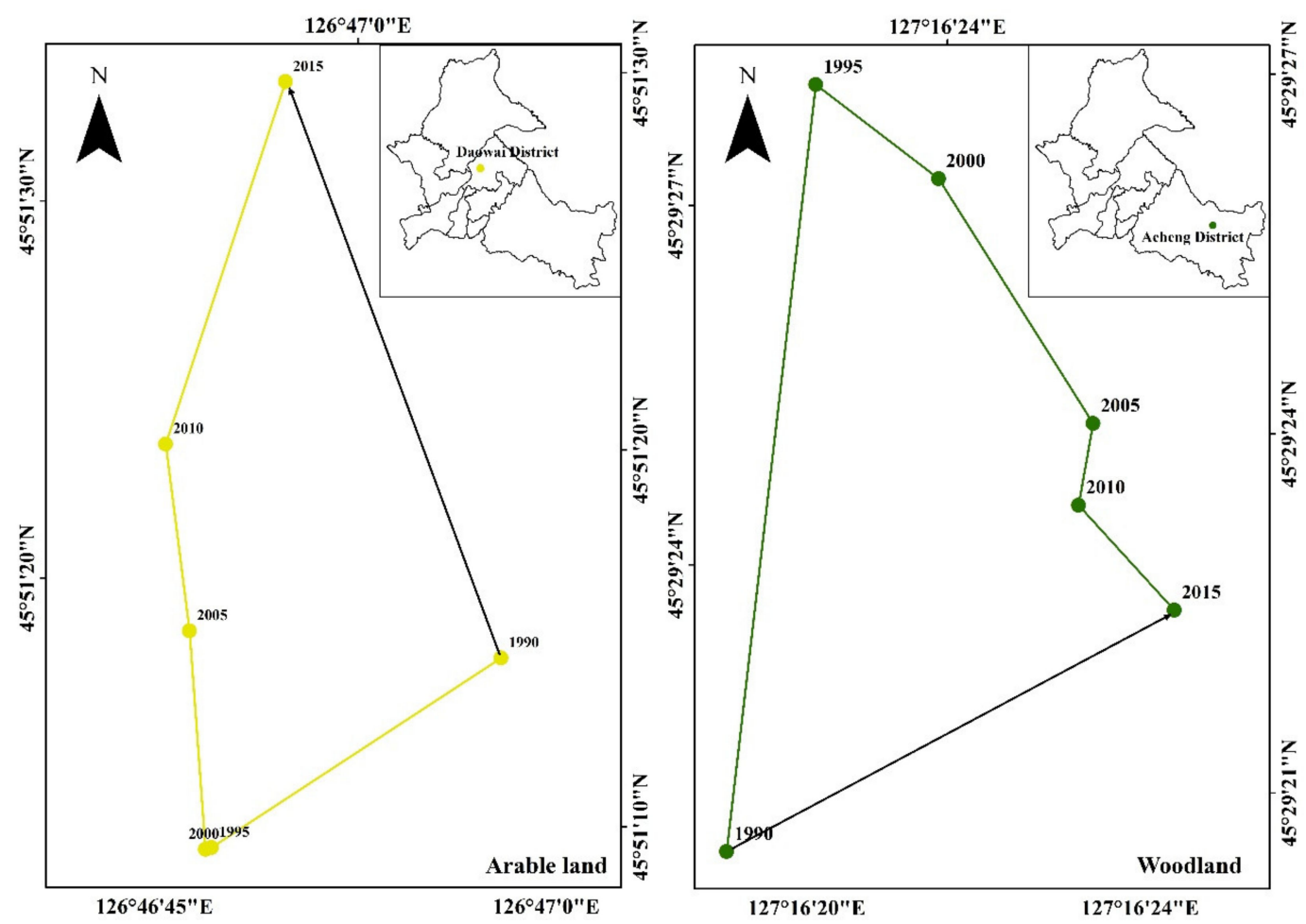

Figure 3. Cont. 

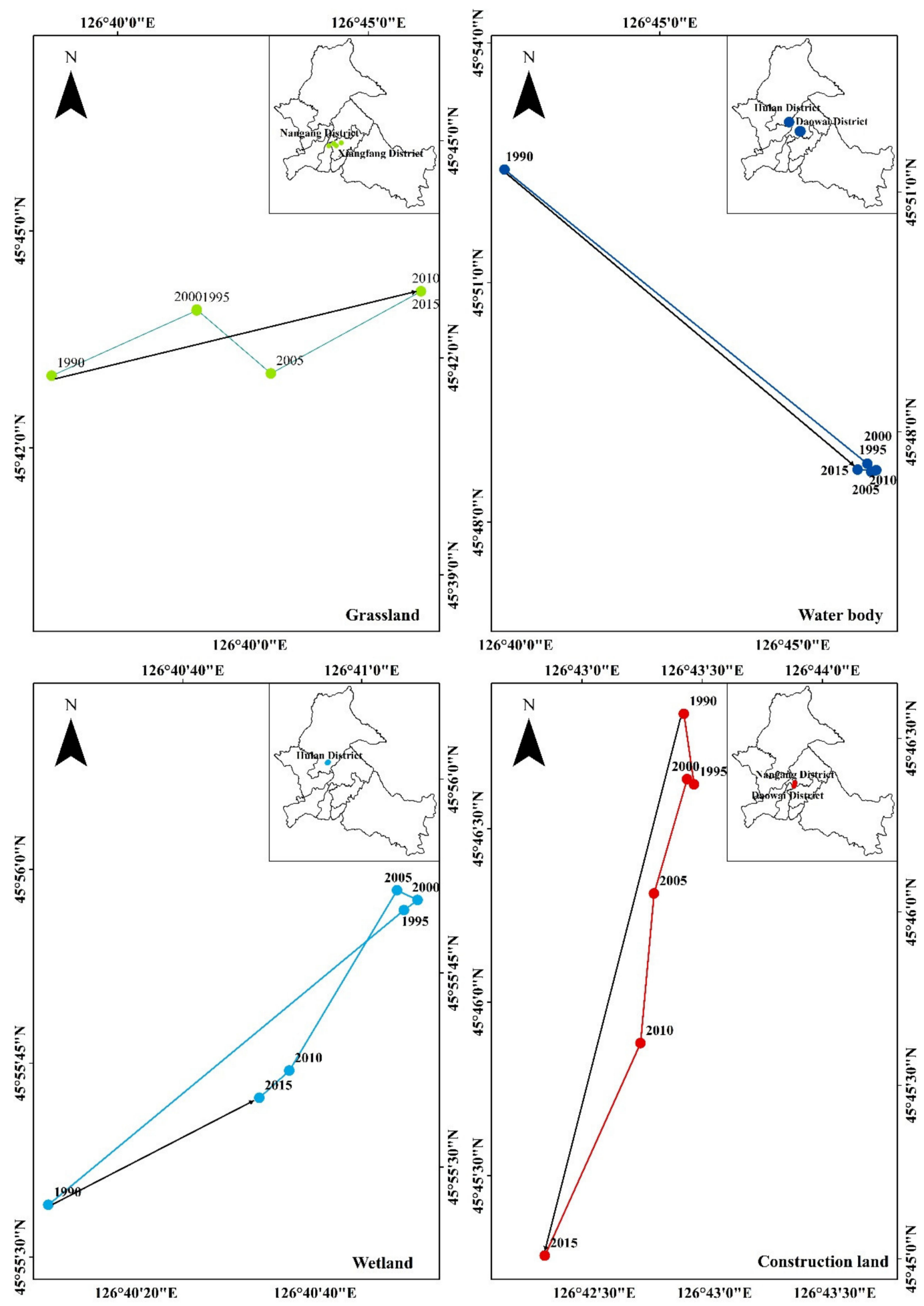

Figure 3. Cont. 

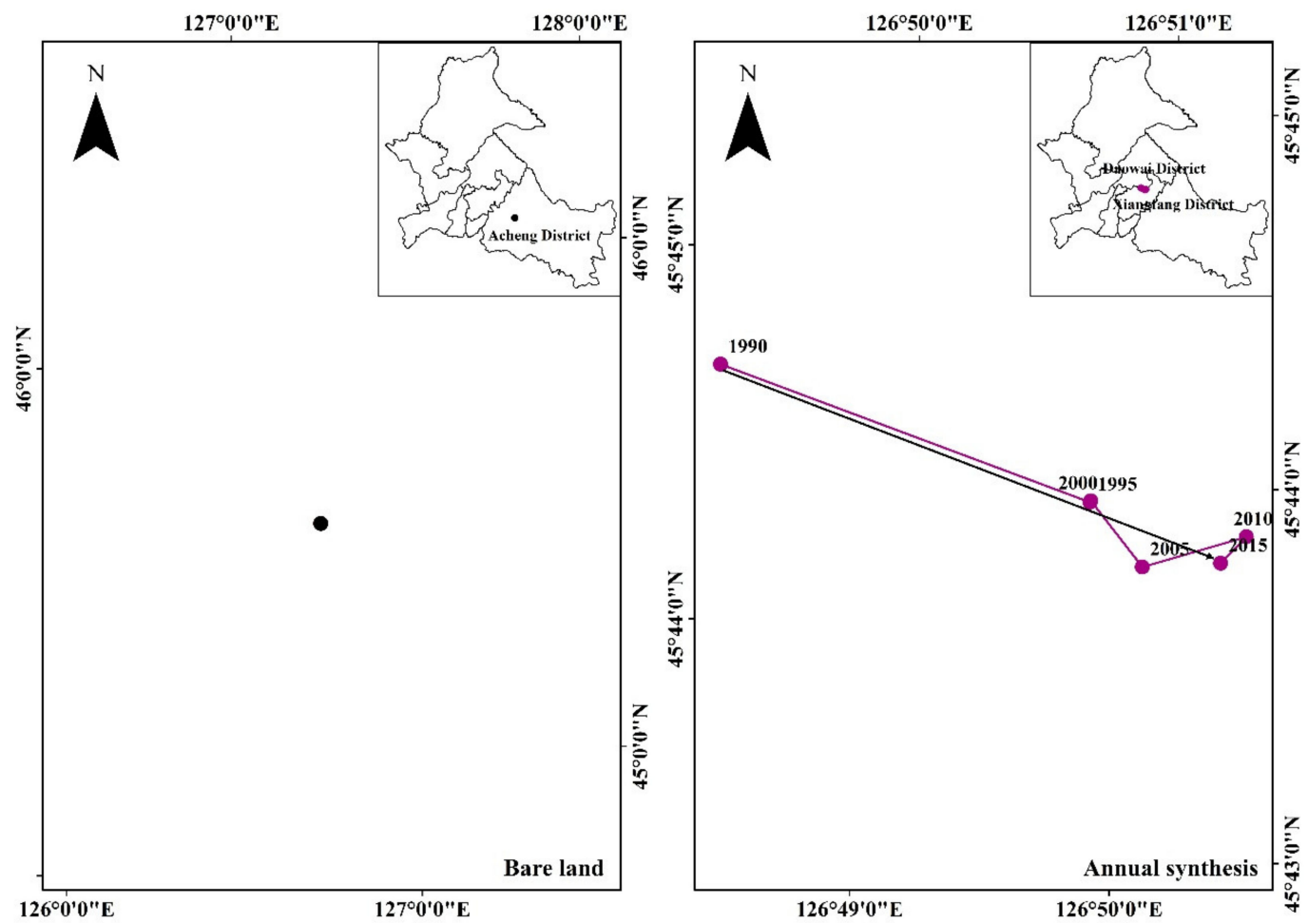

Figure 3. Spatial change transfer map of barycenter of land use/cover center in Harbin main urban district.

With the concept of ecological protection and sustainable development deeply rooted in people's hearts and practices, the depth of urban land use has increased, and the barycenter of construction land has been centralized, moving from the off-road area to Nangang district in general southwest direction and over a distance of about $3068 \mathrm{~m}$. Similar to the above contents, the longest distance over which the barycenter of construction land shifted was reported to be in the period 2010-2015 and was about $1281 \mathrm{~m}$, and the shortest distance was reported in the period 1995-2000 and was about $48 \mathrm{~m}$.

From 1990 to 2015, the three bare lands have not changed. Thus, the barycenter has not changed either; it is located in the northwest part of the Acheng district.

The barycenter of land use/cover shifted from Daowai district to Xiangfang district, over a distance of $2750 \mathrm{~m}$ in the southeast direction from 1990 to 2015. Consistent with the above-mentioned changes and Harbin's "southern expansion" policy, the longest distance of land use/cover barycenter shift was from 1990 to 1995, at about $2015 \mathrm{~m}$, while the shortest distance was reported from 1995 to 2000, at about $8 \mathrm{~m}$ [43-45].

As shown in Table 4, the self-adjacency probability of each type is above $85 \%$. In contrast, the adjacency probability with other types is low, not more than $10 \%$, indicating that each land use/cover type in the study area is relatively concentrated, and the degree of fragmentation is low.

Table 4. Spatial neighborhood probability matrix of land use/cover types in Harbin main urban district in 1990.

\begin{tabular}{cccccccc}
\hline Type of LUCC & $\begin{array}{c}\text { Arable } \\
\text { Land }\end{array}$ & Wood-Land & Grass-Land & $\begin{array}{c}\text { Water } \\
\text { Body }\end{array}$ & Wet-Land & $\begin{array}{c}\text { Construction } \\
\text { Land }\end{array}$ & $\begin{array}{c}\text { Bare } \\
\text { Land }\end{array}$ \\
\hline Arable land & $98.32 \%$ & $0.52 \%$ & $0.12 \%$ & $0.03 \%$ & $0.23 \%$ & $0.78 \%$ & $0.004 \%$ \\
Woodland & $1.83 \%$ & $98.17 \%$ & $0.17 \%$ & $0.07 \%$ & $0.14 \%$ & $0.14 \%$ & $0.01 \%$ \\
Grassland & $6.10 \%$ & $2.39 \%$ & $90.69 \%$ & $0.11 \%$ & $0.19 \%$ & $0.52 \%$ & 0 \\
Water body & $1.50 \%$ & $1.13 \%$ & $0.12 \%$ & $91.09 \%$ & $5.49 \%$ & $0.66 \%$ & 0 \\
Wetland & $1.86 \%$ & $0.33 \%$ & $0.03 \%$ & $0.80 \%$ & $96.79 \%$ & $0.19 \%$ & 0 \\
Construction land & $8.27 \%$ & $0.42 \%$ & $0.11 \%$ & $0.13 \%$ & $0.26 \%$ & $90.82 \%$ & 0 \\
Bare land & $6.95 \%$ & $4.46 \%$ & 0 & 0 & 0 & 0 & $88.59 \%$ \\
\hline
\end{tabular}


From a single type of spatial self-adjacency, the study area has the highest probability of arable land and woodland self-adjacency, with $98.32 \%$ and $98.17 \%$, respectively, indicating that arable land and forest land are mostly concentrated and contiguous, with strong spatial aggregation. Although there is greater than $90 \%$ probability of grassland, water body, wetland, and construction land being adjacent to each other, this probability is smaller than that of adjacency between arable land and woodland, which indicates that the spatial aggregation of these land use/cover types is lower than that of arable land and woodland, and their distribution is relatively loose. Compared with other types, the probability of self-adjacency was lowest for the bare land, and only adjacent to the arable land and woodland.

According to the different types of spatial adjacency, except the probability of adjacency of water body to wetland, the adjacency probability of various types with arable land is higher than that of other types, which indicates that arable land holds an absolute advantage area in the whole research area, and the highest adjacency probability was the construction land. Construction land is mainly surrounded by arable land; hence arable land is the main source of construction land area expansion.

From the conversion trend between the same types, as shown in Figure $4 \mathrm{a}$, the indices of arable land and woodland are 0.98 and 0.99 , respectively, approaching 1, which indicates high stability. Although the change area of arable land in the study area is in the highest proportion, its base number is large and the probability of self-adjacency is high; woodland is concentrated in the southeast of the study area, with high probability of self-adjacency and low proportion of change area. Therefore, arable land and woodland have higher self-stability and lower dynamic degrees. The indexes of grassland, water body, and wetland are the lowest at $0.70,0.94$, and 0.92, respectively, indicating relatively poor stability and ease of transformation to other categories. The water body has a higher tendency index of transforming to the same type compared to wetland, because it is surrounded by wetland. At the early stage of research, the proportions of grassland, water body, and wetland in the seven types in the study area were relatively low. Although the proportion of change area is low, its dynamic degree is high, and its self-stability is poor. The index of construction land and bare land is higher than 1 , which indicates that the two types are relatively stable and are less likely to be converted to other types of land use under the conditions of adjacency. During the 25 years, only 3.8\% of the construction land in the research area was transferred to other types, $31.5 \%$ from other types, a net increase of about one third of the area in 1990. The area of bare land has not changed, nor has it been transferred out of or from other types.

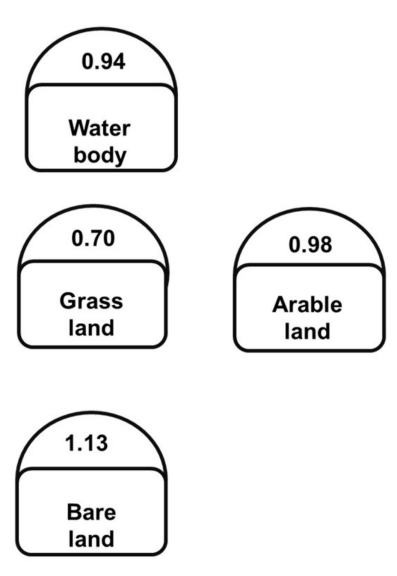

(a) Between same types

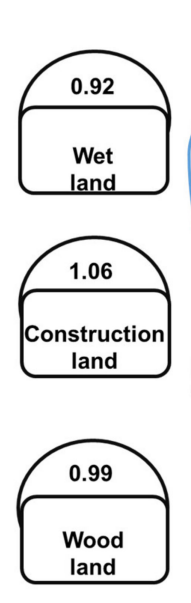

land

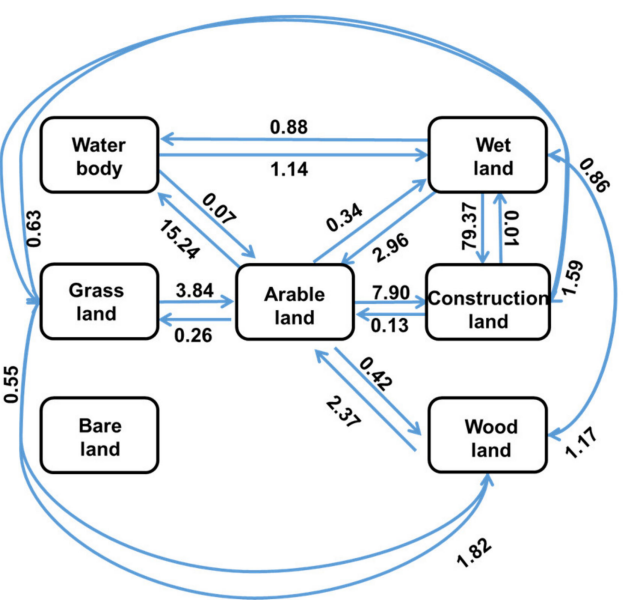

(b) Between different types

Figure 4. Trend index of conversion tendency from 1990 to 2015. (In the figure, the trend index without conversion tendency does not mean that it is impossible, but only that its possibility is very small, and this type of land has strong stability.) 
Judging from the conversion trend between different types, as shown in Figure $4 \mathrm{~b}$, the index of arable land to water body is 15.24, however, it is not in conformance with the above contents, which indicates that Songhua River passing through the central part of Harbin City may cause a waterlogging disaster and poses the risk of affecting short-term use of the adjacent arable land. Secondly, the trend index of conversion to construction land is 7.90, which indicates that a large amount of arable land has been occupied by construction land during the urbanization process in the past 25 years. The trend index of conversion of woodland and grassland to arable land is the highest among the conversion indices to other categories, and the adjacent probability is also the highest, which indicates that while arable land is converted to construction land, high-quality and adjacent ecological land such as woodland and grassland is converted to arable land for production to maintain the output of Harbin's primary industry. The trend index of woodland conversion to construction land is zero because woodland is concentrated in the southeast of Acheng district, whereas construction land is concentrated in the junction of Songbei district, Daoli district, Nangang district, Xiangfang district, and Daowai district, and the "southern expansion" policy has not yet touched Acheng district. Therefore, conversion of woodland into construction land is less likely to occur. The trend index of water body turning into arable land and wetland is 0.07 and 1.14, respectively. The trend index of wetland conversion to construction land is as high as 79.37 , and the trend index of wetland conversion to arable land is 2.96 , which is the same as the above quantitative changes and spatial distributions. The trend index of conversion of construction land to other types is very small or zero, which indicates that it is stable. The trend index of bare land transformation to the other six categories is zero, indicating strong stability. This is also consistent with the quantity, spatial distribution, and change of the seven types in the study area over the past 25 years.

Table 5 shows that the conversion trend of arable land, woodland, grassland, and wetland in the study area has little relation with its own probability of adjacency, and the water body correlation coefficient is not too high. This is because of the following reasons: (1) The arable land is adjacent to the other six types; however, the research area is the main urban area, and its development will be dominated by construction land. (2) The woodland in the study area is concentrated in the southeast of Acheng district, which is an important ecological land and is also the main reserve resource of arable land. (3) The proportion of grassland in the study area is located on the terrace formed by Songhua River, which is the main source of the transferred area of arable land and construction land. (4) Due to the development policy formulated by the study area- "Wanqing Songiang Wetland, Baili Ecological Corridor" policy - the protection, restoration, and construction of wetlands and water bodies are not significantly correlated with the probability of spatial adjacency, and its transfer-out is subject to human intervention.

Table 5. Correlation between spatial neighborhood probability and conversion trend index.

\begin{tabular}{cccccccc}
\hline Type of LUCC & $\begin{array}{c}\text { Arable } \\
\text { Land }\end{array}$ & Wood-Land & Grass-Land & $\begin{array}{c}\text { Water } \\
\text { Body }\end{array}$ & Wet-Land & $\begin{array}{c}\text { Construction } \\
\text { Land }\end{array}$ & Bare Land \\
\hline Coefficient & -0.20 & 0.18 & -0.08 & 0.60 & -0.17 & 0.84 & 1.00 \\
\hline
\end{tabular}

The correlation coefficient of construction land is above 0.8 , indicating a strong correlation. Urban development begins with land urbanization. The expansion of construction land not only requires consideration of social factors, but also examination of natural conditions to reduce investment and risks. Therefore, its spatial correlation probability will be considered in advance during transfer-in and transfer-out.

As a central city area, the research area must mainly use construction land for development. However, the proportion of arable land needs to be stable to maintain normal social development and sustain people's daily lives. Therefore, according to Table 6 and the basic context of social development, the future LUCCs in the study area can be roughly predicted. For social development, the construction land must be expanded, and the main source of the expansion land is the arable land in the research 
area. However, to ensure the output of the primary industry, the research area should be transferred from other types-woodland will be the main source. This is because: (1) The existing area of the grassland itself is not large to support landscape pattern and ecosystem services, the existence of the grassland must be assured, and increasing it is the best strategy. (2) The water body and wetland had begun to implement protection policies, hence controlling the uses. (3) The bare land can be converted into arable land for use, but its area is only $2.68 \mathrm{~km}^{2}$, which does not account for much.

Table 6. Degree of ecological economic harmony (EEH) in Harbin main urban district.

\begin{tabular}{ccccccc}
\hline & 1990-1995 & 1995-2000 & 2000-2005 & 2005-2010 & 2010-2015 & 1990-2015 \\
\hline \multirow{2}{*}{ EEH type } & $\begin{array}{c}\text { Potential } \\
\text { crisis zone }\end{array}$ & $\begin{array}{c}\text { Moderate } \\
\text { coordination zone }\end{array}$ & $\begin{array}{c}\text { Low coordination } \\
\text { zone }\end{array}$ & $\begin{array}{c}\text { Low coordination } \\
\text { zone }\end{array}$ & $\begin{array}{c}\text { Low coordination } \\
\text { zone }\end{array}$ & $\begin{array}{c}\text { Potential } \\
\text { crisis zone }\end{array}$ \\
\hline
\end{tabular}

\subsection{Ecosystem Service Value}

As shown in Figure 5, the value of arable land and woodland accounts for about one third in the ecosystem service system of the study area, respectively, with only a small change over the past 25 years, not more than $0.5 \%$, and an overall increasing trend. The value proportions of grassland and water body are also not large. The highest proportion of grassland was $1.01 \%$ in 1990, and the proportion gradually decreases. The proportion of water body is less than $4 \%$, with an overall increasing trend. Wetland occupies the third place of the seven types, with the largest change ratio decreasing by $1.09 \%$ in 25 years. The service value ratio and change ratio of construction land and bare land as non-ecological land are not large. Construction land increased by $0.1 \%$, and bare land remained unchanged.

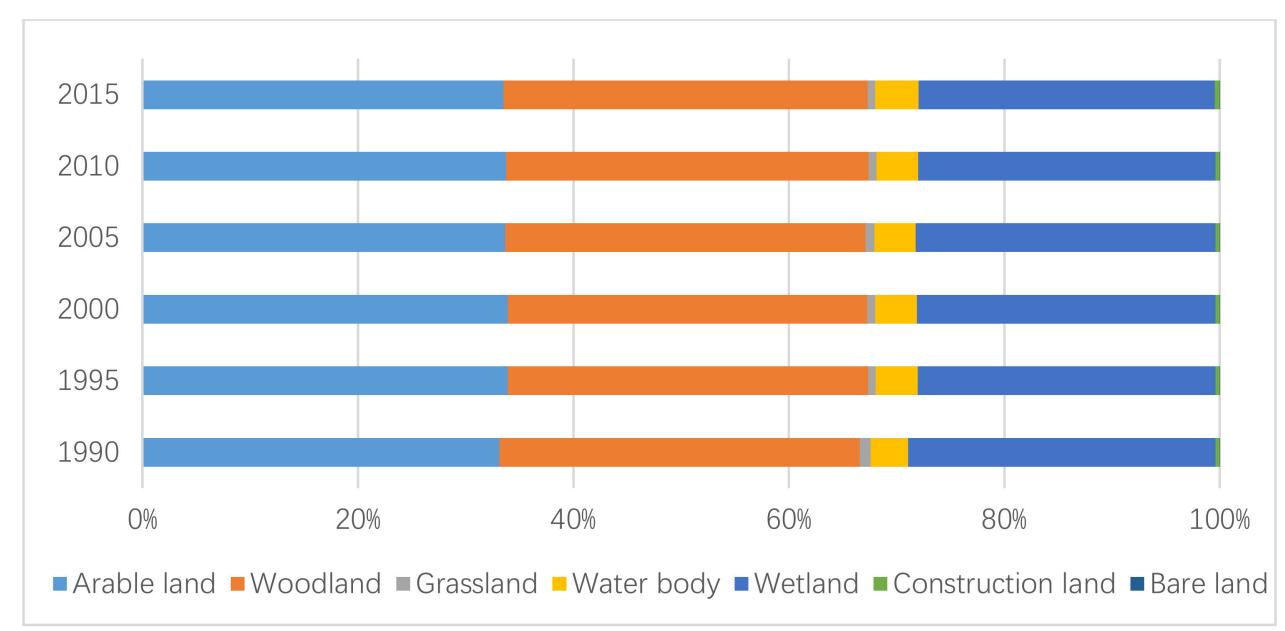

Figure 5. Percentage of ecosystem service value in Harbin main urban district.

The data in the previous section show that among the seven types of land use/cover in the study area, there was no change in the bare land area, the water body and construction land area increased, while the other types decreased. However, with the development of science and technology, the efficiency of land use has improved, so the composition of ecosystem service value has decreased slightly, except in the grassland and wetland. The cumulative change of all the types is the same as above, and the change is small.

The value of ecosystem services derives from land use and change with the land use/cover in the past 25 years. As shown in Figure 6, the ecosystem service value of Hulan district, Songbei district, Daoli district, Daowai district, and Xiangfang district, which account for an increasing proportion of non-ecological land; construction land, has obviously decreased. The ecosystem service value is inclined to Acheng district, which accounts for a large proportion of woodland. Among them, the ecosystem service value of Songhua River Basin has increased due to the implementation of environmental protection policies [22]. 

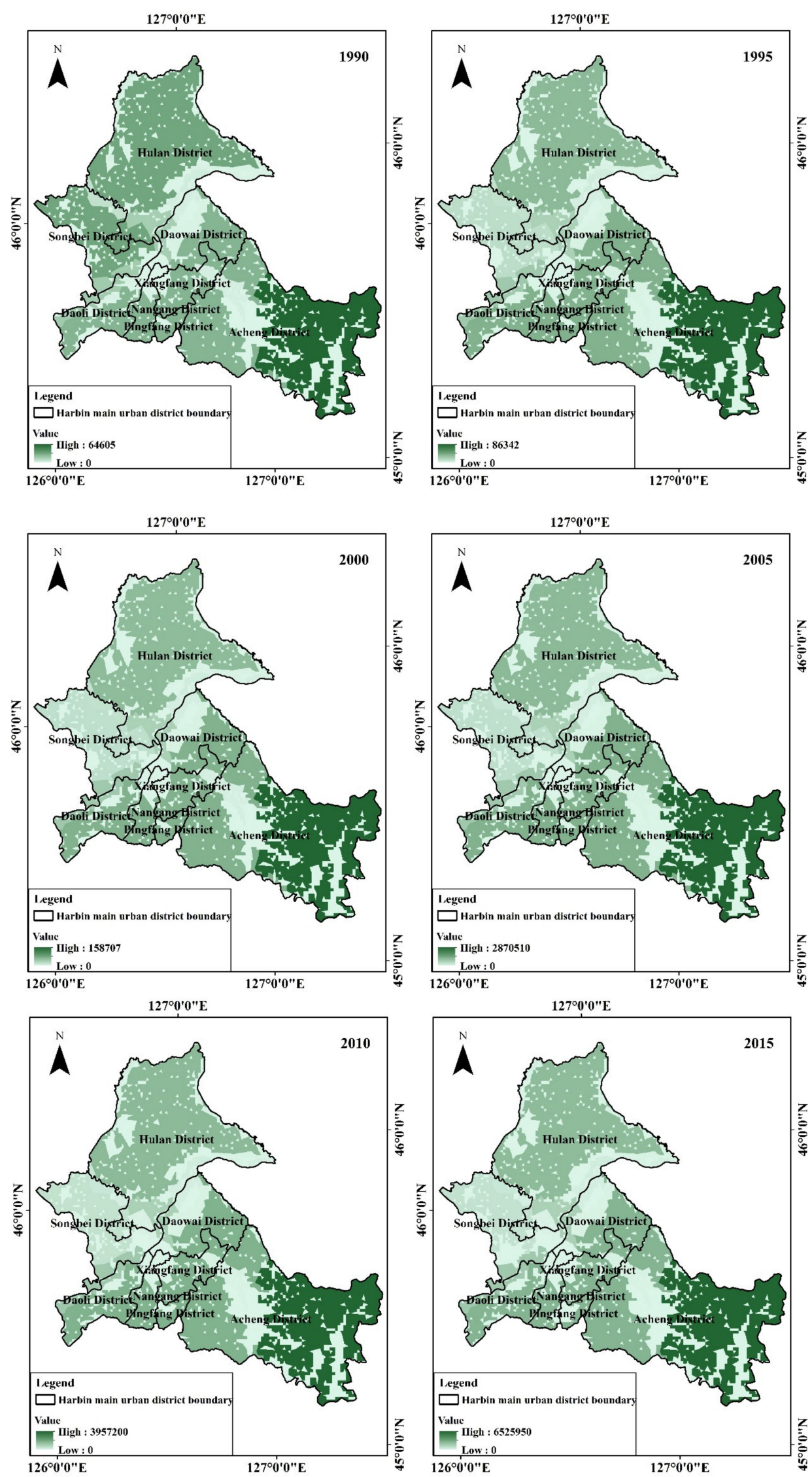

Figure 6. Distribution map of ecosystem service value (ESV) in Harbin's main urban district. 


\subsection{Ecological Economic Harmony}

Table 6 shows that Harbin's ecological environment and economic state have not really formed a coordinated state. The research period of this article started from 1990, when the overall level of science and technology in China was low, the land utilization rate was low, and the ecosystem service value of land resources was not fully portrayed, which affected economic development. Therefore, the degree of eco-economic harmony in the research area indicated a potential crisis zone from 1990 to 1995. After that, the value of ecosystem services in the study area increased rapidly under the joint effect of scientific and technological progress and economic development, and the degree of eco-economic harmony increased to moderate coordination zone between 1995 and 2000.

However, the financial crisis that began in the 20th century, the backwardness of the property rights system and the industrial structure in the three northeastern provinces, the slow population growth and the lack of vitality in industrial development, have resulted in the economic downturn in the research area and the growth of GDP is lower than that of ecosystem services. More articles have pointed out that the GDP growth of the three northeastern provinces in the first three quarters of 2014 in the bottom five among China's 31 provinces, far below the national average. However, under such circumstances, the extensive economic growth mode makes the growth rate of the ecosystem service value in the research area also begin to be at a low level. Therefore, the degree of eco-economic harmony in the research area started in 2000 has declined to a low coordination zone [38-42].

\section{Discussion}

For the development of every city, arable land will be the main source of construction land expansion. However, the proportion of arable land needs to be stable to maintain normal social development and sustain people's daily lives. As the capital city of a major grain-producing province, the arable land proportion of the study area fluctuates up and down over the years, but its overall arable land area accounts for more than $60 \%$ of the whole study area and accounts for one third of the whole ecosystem service value of the study area. The area of arable land transferred out is the largest of the seven types; $73.5 \%$ of the transferred area was converted to construction land, accounting for $90 \%$ of the increased construction land area. It should be noted that the tendency index of conversion to water body is as high as 15.24 , which is related to the location of arable land. Harbin is a key city for flood control in China. Most of the arable land is located on both sides of Songhua River which passes through Harbin. Heavy rain is therefore likely to result in a short-term waterlogging disaster, affecting the normal use of arable land [46,47].

Urbanization is the inevitable trend of the development of human society and the inevitable outcome of economic and technological progress. Urban fringe expansion and resource urbanization are inevitable. As a central city in northeast China, the urbanization development of the research area over the years is obvious to all. The new development strategy of "North Jump, South Extension, Central Prosperity and Strong County" formulated by the seventh Plenary Session of the 12th Harbin Municipal Committee of the CPC (Communist Party of China), has detailed Harbin's future plan. Looking up the data, we can find that, in addition to the expansion of construction land in the central area of the research area, Songbei New district has recently built a new high-tech development zone, The World of Ice and Snow, The Siberian Tiger Park. Similar to the interpreted image data, the changed areas for construction land are distributed in Songbei district, Pingfang district, Nangang district, and Xiangfang district, significantly reducing the value of ecosystem services in the central region where the center of Harbin's main urban area is located. This shows the same trend as the urbanization process in most cities in many developing countries. The rapid expansion of construction land at the expense of ecological land has led to a significant reduction in the value of ecosystem services in the areas developed [48-51].

The proportion of ecosystem service value has not changed much in the past 25 years, but with the shift in the land use/cover barycenter, the ecosystem service value in space inclines to Acheng district. The coordination of eco-economy changes greatly, which indicates that the degree of coordination of 
eco-economic systems in the research area is poor and may destroy the environment and restrict future economic development. This is similar to China's current process of urbanization, the acceleration of urbanization of land resources, threats to ecological land, and the increasingly prominent contradiction between the allocation of ecological land and non-ecological land [52,53].

As an "internationally wetland city" certified by the United Nations as a characteristic "wetland in city, city beside wetland," the wetland and water body resources in the research area are valuable wealth for future development, and the ecological services that can be provided play a decisive role. The increase in the area of water body in ecological land and the high proportion of mutual conversion between wetland and water body are due to the development strategy of "Wanqing Songjiang Wetland and Baili Ecological Corridor." which started in the 11th Five-Year Plan., The strategy has entailed the protection, restoration, and key construction of the existing wetland resources, and has established three wetland nature reserves and two wetland parks along the Songhua River [44,45]. It is also a template for future development and implementation of other similar policies in China or in developing countries.

The use of resources is necessary for social development. The value of ecosystem services derives from land use. Due to a lack of awareness and underdeveloped technology, China's previous economic growth has had a negative impact on the ecosystem. It is now shifting to a more intensive form of economic growth, improving efficiency and reducing resource inputs and consumption. The formulation and implementation of various policies and institutional reforms have all demonstrated China's understanding and emphasis on the coordinated development of the economy and the ecological environment.

Although there are some policies to protect the ecological environment, urban development and urbanization of land resources are inevitable, and the distribution contradiction between ecological land and non-ecological land is becoming increasingly obvious. Therefore, in future development, while paying attention to economic development and supply-side reform, China's attention should also be paid to the ecological land structure, ecological safety, sustainable development, continuous enrichment of the dialectical relationship between economic development and ecological protection, and turning "Lucid Waters and Lush Mountains are Invaluable Assets" into vivid reality in practice. It also can provide some experience and lessons for other countries.

\section{Conclusions}

In this study, eight major urban areas in Harbin are taken as the study area, and six phases of land use/cover image data for 25 years from 1990 to 2015 are taken as research data to study their LUCC, ESV, and EEH. The land use/cover types are divided into seven types, and the following results are obtained:

(1) In the past 25 years, the absolute values of the seven types of dynamic degrees are not more than $1.5 \%$. The highest dynamic degree was construction land. The barycenter of other types move, with the exception of bare land. The barycenter of total land use/cover change in the study area moved $2750 \mathrm{~m}$ to the southeast of the study area. Among them, the moving distances of water body, construction land, and grassland are the longest. The degree of movement of the overall change is the same as that of the change characteristics of quantitative structural of land use/cover changes.

(2) The self- adjacency probability of arable land and woodland is as high as $98 \%$ in the spatial adjacency probability of land use/cover types, high self-stability. In the past 25 years, only the self- adjacency probability between water body and construction land has increased. Excluding water body, for conversion to cultivated land or construction land, the change index of each type is greater than the reverse index.

(3) It is roughly predicted that future land use changes in the study area will mainly occur in three types: Construction land, arable land, and forest land. The expansion of construction land uses arable land as its main source. In order to maintain the output of arable land, woodland is the main source. 
(4) The value of ecosystem services, quantitatively, has changed little over 25 years. Spatially, it is skewed towards Acheng district. The quantitative and spatial trends are consistent with changes in land use/cover change attitudes and shifts in focus.

(5) During the past 25 years, the total degree of eco-economic coordination has been in a potential crisis zone. From the potential crisis zone in 1990-1995, it rose to a moderate degree of coordination, and dropped to a low degree of coordination after 2000.

Author Contributions: All authors contributed meaningfully to this study. Conceptualization, D.R., Z.T. and J.Z.; Data curation, D.R., X.Z. and A.W.; Supervision, Z.T. and J.Z.; Writing—original draft, D.R.; X.Z. and A.W. offered data support for this work. All authors have read and agreed to the published version of the manuscript.

Funding: This research was funded by the Key Scientific and Technology Program of Jilin Province, (China) (20170204035SF); the Science and Technology Development Planning of Jilin Province, (China) (20190303081SF).

Acknowledgments: The authors would like to thank the Data Center for Resources and Environmental Sciences, Chinese Academy of Sciences (RESDS, http://www.resdc.cn) for providing the land use dataset.

Conflicts of Interest: The authors declare no conflict of interest.

\section{References}

1. Xie, H.; Liu, Z.; Wang, P.; Liu, G.; Lu, F. Exploring the mechanisms of ecological land change based on the spatial autoregressive model: A case study of the Poyang Lake Eco-Economic Zone, China. Int. J. Environ. Res. Public Health 2013, 11, 583-599. [CrossRef]

2. Foley, J.A.; Defries, R.; Asner, G.P.; Barford, C.; Bonan, G.; Carpenter, S.R.; Chapin, F.S.; Coe, M.T.; Daily, G.C.; Gibbs, H.K.; et al. Global consequences of land use. Science 2005, 309, 570-574. [CrossRef] [PubMed]

3. Zhang, H.; Zhai, C.; Zhang, X. Forecasting water resources demand based on complex system dynamics: A case study of Tianjin City. In Proceedings of the 2008 International Seminar on Future BioMedical Information Engineering, Hong Kong, 18 December 2008; pp. 415-417.

4. Qiu, L.; Pan, Y.; Zhu, J.; Amable, G.S.; Xu, B. Integrated analysis of urbanization-triggered land use change trajectory and implications for ecological land management: A case study in Fuyang, China. Sci. Total Environ. 2019, 660, 209-217. [CrossRef] [PubMed]

5. Zhang, Q.; Gao, M.; Yang, L. Changes in the spatial structure of ecological land and ecosystem service values in nine key districts of Chongqing City over the past 25 years. Acta Ecol. Sin. 2017, 37, 566-575.

6. Yu, F.; Li, X.B.; Zhang, L.J.; Xu, W.H.; Fu, R.; Wang, H. Study of ecological land in China: Conception, classification, and spatial temporal pattern. Acta Ecol. Sin. 2015, 35, 4931-4943.

7. Lambin, E.F.; Baulies, X.; Bockstael, N. Land-use and land-cover change: Implementation strategy. In IGBP Report No.48/IHDP Report No.10; IGBP: Stockholm, Sweden, 1999.

8. IGBP Secretariat. GLP Science Plan and Implementation Strategy. In IGBP Report No. 53/IHDP Report No.19; IGBP: Stockholm, Sweden, 2005.

9. Turner, B.N.; Lambin, E.F.; Reenberg, A. The emergence of land change science for global environmental change and sustainability. Proc. Natl. Acad. Sci. USA 2007, 104, 20666-20671. [CrossRef] [PubMed]

10. Mooney, H.A.; Duraiappah, A.; Larigauderie, A. Evolution of natural and social science interactions in global change research programs. Proc. Natl. Acad. Sci. USA 2013, 110, 3665-3672. [CrossRef]

11. Sterling, S.M.; Ducharne, A.; Polcher, J. The impact of global land-cover change on the terrestrial water cycle. Nat. Clim. Chang. 2013, 3, 385-390. [CrossRef]

12. Tong, S.; Dong, Z.; Zhang, J.; Bao, Y.; Guna, A.; Bao, Y. Spatiotemporal variations of land use/cover changes in Inner Mongolia (China) during 1980-2015. Sustainability 2018, 10, 4730. [CrossRef]

13. Zhou, T.; Li, T.H. Influence of land use/cover changes on ecosystem services in Shaanxi Province before and after returning farmland to forest/grass. Res. Soil Water Conserv. 2014, 21, 246-250.

14. Cao, K.Y. Research on the Paths of the Redevelopment of Low-Efficiently Used Land under the Background of New Urbanization, by the Example of Xiaoshan District of Hangzhou. Master's Thesis, Northwest University, Xian, China, 2016.

15. Zhou, L. Research on classification standard and quality system of dynamic information of digital city spatial governance. In Proceedings of the Geospatial Information Technology and Digital Jiangsu Forum, Nanjing, China, 20 November 2001. 
16. Jia, M.Y. Transformed biological city-Malmo of Sweden. Urban Manag. Sci.Technol. 2018, 20, 84-85.

17. Wan, J.; Qin, C.B.; Yu, L.; Lu, H.B. Ideas and suggestions on speeding up the establishment of "Three Lines and One List". Environ. Prot. 2017, 45, 7-9.

18. Meyfroidt, P.; Lambin, E.F.; Erb, K.H.; Hertel, T.W. Globalization of land use: Distant drivers of land change and geographic displacement of land use. Curr. Opin. Environ. Sustain. 2013, 5, 438-444. [CrossRef]

19. Qiao, W.; Sheng, Y.; Fang, B.; Wang, Y. Land use change information mining in highly urbanized area based on transfer matrix: A case study of Suzhou, Jiangsu Province. Geogr. Res. 2013, 32, 1497-1507.

20. Pontius, R.G.; Boersma, W.; Castella, J.C.; Clarke, K.; Nijs, T.D.; Dietzel, C. Comparing the input, output, and validation maps for several models of land change. Ann. Reg. Sci. 2008, 42, 11-37. [CrossRef]

21. Krajewski, P.; Solecka, I.; Mastalska-Cetera, B. Landscape change index as a tool for spatial analysis. J. IOP Mater. Sci. Eng. 2017, 245, 072014. [CrossRef]

22. Zhu, X.M. The Spatiotemporal Change and Scenario Simulation of Ecological Land Pattern in Harbin Based on CLUE-S Model. Master's Thesis, Northeast Normal University, Changchun, China, 2019.

23. The State Council Approved Harbin City Master Plan (2011-2020). Urban Plan. Newsrep. 2011, 11, 2-3.

24. Forkuor, G.; Cofie, O. Dynamics of land-use and land-cover change in Freetown, Sierra Leone and its effects on urban and peri-urban agriculture-A Remote Sensing Approach. Int. J. Remote Sens. 2011, 32, 1017-1037. [CrossRef]

25. Zhang, L.; Yang, G.F.; Liu, J.P. The Dynamic Changes and Hot Spots of Land Use in Fushun City from 1986 to 2012. Sci. Geogr. Sin. 2014, 34, 185-191.

26. Wang, X.L.; Bao, Y.H. Study on the methods of land use dynamic change research. Prog. Geogr. 1999, 018, 3-5.

27. Zhu, H.Y.; Li, X.B. Discussion on the index method of regional land use change. Acta Geogr. Sin. 2003, 58, 643-650.

28. Narisu. Spatio-Temproal Variation Characteristics of Desertification in Hulunbeier Sandy Land. Master's Thesis, Inner Mongolia Normal University, Hohhot, China, 2017.

29. Gao, Z.Q.; Liu, J.Y.; Zhuang, D.F. The dynamic changes of the gravity center of the farmland area and the quality of the farmland area ecological background in China. J. Nat. Resour. 1998, 13, 3-5.

30. Tang, K.J.; Zheng, X.Q.; Yan, H.W.; Dong, J.W. Construction and application of modeling tendency of land type transition based on spatial adjacency. Acta Ecol. Sin. 2009, 29, 337-343.

31. Bai, G.C. Study on the Prediction of Land Use Change Trend in Dongpo District in Meishan City. Master's Thesis, Sichuan Agricultural University, Ya'an, China, 2009.

32. Zeng, C.Y.; Liu, Z.B.; Zeng, G.Y.; Cheng, L.H.; Liao, Y.; Li, B. Analysis on forestland change by using spatial transition matrix model. For. Resour. Manag. 2012, 105-110. [CrossRef]

33. Zhao, G.S.; Liu, J.Y.; Kuang, W.H.; Ouyang, Z.Y.; Xie, Z.L. Disturbance impacts of land use change on biodiversity conservation priority areas across China: 1990-2010. J. Geogr. Sci. 2015, 25, 515-529. [CrossRef]

34. Costanza, R.; D’Arge, R.; De Groot, R.; Farber, S.; Grasso, M.; Hannon, B.; Limburg, K.; Naeem, S.; O'neill, R.V.; Paruelo, J. The value of the world's ecosystem services and natural capital. Nature 1997, 387, 253-260. [CrossRef]

35. Xie, G.D.; Zhen, L.; Lu, C.X.; Xiao, Y.; Chen, C. Expert Knowledge Based Valuation Method of Ecosystem Services in China. J. Nat. Resour. 2008, 23, 911-919.

36. Radford, K.G.; James, P. Changes in the value of ecosystem services along a rural-urban gradient: A case study of Greater Manchester, UK. Landsc. Urban Plan. 2013, 109, 117-127. [CrossRef]

37. Zang, Z.; Zou, X.; Zuo, P.; Song, Q.; Wang, C.; Wang, J. Impact of landscape patterns on ecological vulnerability and ecosystem service values: An empirical analysis of Yancheng Nature Reserve in China. Ecol. Indic. 2017, 72, 142-152. [CrossRef]

38. Zhao, Y.; Wang, S.; Zhou, C. Understanding the relation between urbanization and the eco-environment in China's Yangtze River Delta using an improved EKC model and coupling analysis. Sci. Total Environ. 2016, 571, 862-875. [CrossRef] [PubMed]

39. Wang, Z.B.; Fang, C.L.; Cheng, S.W.; Wang, J. Evolution of coordination degree of eco-economic system and early-warning in the Yangtze River Delta. J. Geogr. Sci. 2013, 23, 147-162. [CrossRef]

40. Wei, X.X.; Zhan, J.; Wei, W.; Xie, B.B. Coordinated development of ecological-economic system and spatial evolution based on county unit in China. Prog. Geogr. 2014, 33, 1535-1545.

41. Su, F.; Zhang, P.Y. Assessment of coordinative development between economy and environment based on ecosystem service values change: A case of Daqing city. Prog. Geogr. 2009, 28, 471-477. 
42. He, H.H.; Li, X.; Dong, F.; Ren, Y.N. Evaluation on Coordination Degree of Eco-economic System in Anhui Province. Econ. Forum 2016, 28-32. [CrossRef]

43. Xie, A.L. An Analysis of Harbin's Planning and Development Strategy of "North Jump, South Extension, Central Prosperity and Strong County". China Sci. Technol. Panor. Mag. 2011, 52. [CrossRef]

44. Interpretation 1 of "Implementation Opinions on Financial Support for Tourism Development in Harbin City". Available online: http://www.harbin.gov.cn/art/2012/9/28/art_727_29748.html (accessed on 16 December 2019).

45. “North Jump, South Extension, Central Prosperity and Strong County" Strategy to Promote Harbin's Strong Development. Available online: http://news.ifeng.com/c/7fckPKTOqR5 (accessed on 16 December 2019).

46. Du, G.Q.; Li, H.Y.; Li, H.; Chen, Y.J.; Jang, X.Y. Study on resilience evaluation of flood disaster urban system in Harbin. Shanxi Archit. 2019, 45, 251-253.

47. Zhang, J.G.; Wang, Y.B.; Wei, F.Y. Cause analysis of flood disaster in Harbin city and discussion on flood control countermeasures. Heilongjiang Sci. Technol. Water Conserv. 2008, 36, 20-21.

48. Xin, R. Simulation of land use change patterns in Harbin area based on CLUE-S model and its prospects. Agric. Outlook 2019, 15, 71-76.

49. Wang, S.B.; Pan, T.; Lei, G.P. Land use pattern and NDVI response characteristics based on Landsat TM in Harbin city. Jiangsu Agric. Sci. 2019, 47, 221-225.

50. Liu, M. Research on the Change of the Land Use for Urban-Rural Construction in Harbin Based on Remote Sensing. Master's Thesis, Northeast Agricultural University, Harbin, China, 2018.

51. Li, Z.M. Study on Temporal and Spatial Characteristics of Land Use Change in Harbin. Master's Thesis, Northeast Agricultural University, Harbin, China, 2018.

52. Liu, H.Y. Research on urban land security in China's urbanization process. Ph.D. Thesis, Institute of Geographic Sciences and Natural Resources Research, Beijing, China, 2008.

53. Gai, Z.X.; Sun, P.; Zhang, J.Q. Land Use Change and Formation Mechanism in Songhuajiang Basin-Harbin Section as an Example. Res. Soil Water Conserv. 2019, 26, 314-320.

(C) 2020 by the authors. Licensee MDPI, Basel, Switzerland. This article is an open access article distributed under the terms and conditions of the Creative Commons Attribution (CC BY) license (http://creativecommons.org/licenses/by/4.0/). 